\title{
Valproic Acid Positive Effects in Parkinson’s Disease
}

\section{Amos Gelbard*}

Zefat Academics Kibbutz Eilon, Galil Maaravi, Israel

*Corresponding author: Amos Gelbard, Zefat Academics Kibbutz Eilon, Galil Maaravi, Israel, Tel: 1-800-344-544; E-mail: amosgelbard@gmail.com

Rec date: Aug 01, 2016; Acc date: Aug 03, 2016; Pub date: Aug 06, 2016

Copyright: (C) 2016 Gelbard A. This is an open-access article distributed under the terms of the Creative Commons Attribution License, which permits unrestricted use, distribution, and reproduction in any medium, provided the original author and source are credited.

Citation: Gelbard A (2016) Valproic Acid Positive Effects in Parkinson's Disease. J Neurol Disord 4: 287. doi:10.4172/2329-6895.1000287

Keywords: Parkinson's disease (PD); Valproic acid; Possible treatment

\section{Opinion}

According to a research, Parkinson's disease is characterised by degeneration of Dopaminergic cells in the substantia nigra pars compacta.

The pars compacta is a part of the substantia nigra which is located in an area of the brain called the basal ganglia (Figure 1).

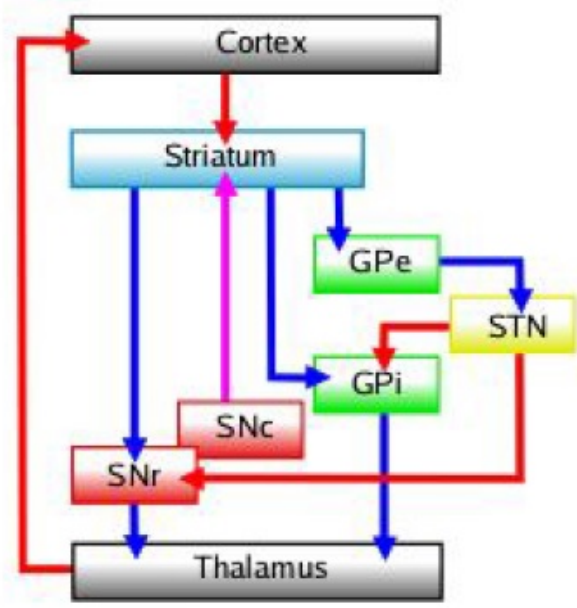

Figure 1: Pathway of Parkinson's disease characterised by the degeneration of dopaminergic cells in the substantia nigra pars compacta.
Above is a flow-chart describing the pathway of Parkinson's disease characterised by the degeneration of dopaminergic cells in the substantia nigra pars compacta located in the basal ganglia [1]. The SNc (Substantia Nigra Pars Compacta) is what that is affected by Parkinson's disease and evidently its influence is only one way, it is unimpacted by any other part of the ganglia.

Valproic acid is a substance that is known to cause Parkinson-like symptoms. Its effect is supposedly, exactly the negative of curing Parkinson's but it is possible that it could also serve to reverse the path of influence through the ganglia and allow positive results in patients.

In a recent study, Brazilian researches showed a decisive indication for valproic acid to be effective against Parkinson's disease, although in Mice that were treated for just two weeks [2].

Their experiment showed that VA partly reversed the behavioral, neurochemical, histological and immune-histochemical alterations observed in the untreated 6 OHDA lesion animals, the results were decisive, even if not conclusive and prove the above logic to possibly have some merit.

Further studies are necessary to examine exactly the impact of treating Parkinson's disease patients with valproic acid.

\section{References}

1. Wikipedia, 'Substantia Nigra'. https:/en.m.wikipedia.org/wiki/ Substantia_nigra

2. Ximenes JCM, Neves KRT, Leal LKA, Carmo MRSD, Brito GNC, et al. (2015) Valproic acid neuroprotection in the 6 OHDA model of Parkinson's disease is possibly related to its antiinflammatory and HDAC inhibitory properties. 